\title{
Modification of Ordinary Concrete Using Fly Ash from Combustion of Municipal Sewage Sludge
}

\author{
Gabriela Rutkowska ${ }^{1}$, Piotr Wichowski ${ }^{2}{ }^{\oplus}$, Małgorzata Franus ${ }^{3}$, Michał Mendryk ${ }^{2}$ and \\ Joanna Fronczyk 1,*iD \\ 1 Institute of Civil Engineering, Warsaw University of Life Sciences-SGGW, Nowoursynowska 166, \\ 02-787 Warsaw, Poland; gabriela_rutkowska@sggw.pl \\ 2 Institute of Environmental Engineering, Warsaw University of Life Sciences-SGGW, Nowoursynowska 166, \\ 02-787 Warsaw, Poland; piotr_wichowski@sggw.pl (P.W.); michal_mendryk@outlook.com (M.M.) \\ 3 Faculty of Civil Engineering and Architecture, Lublin University of Technology, Nadbystrzycka 40, \\ 20-618 Lublin, Poland; m.franus@pollub.pl \\ * Correspondence: joanna_fronczyk@sggw.pl
}

Received: 7 October 2019; Accepted: 7 January 2020; Published: 19 January 2020

\begin{abstract}
This article focuses on the impact of fly ash from the combustion of municipal sewage sludge (FAMSS) as a cement additive in the amounts of 5\%,10\%, 15\%, 20\% and $25 \%$ (by mass) on selected concrete properties. In the course of the experimental work, water penetration depth and compressive strength measurements were made at various periods of curing (from 2 to 365 days). In addition, the potential impact of FAMSS on the natural environment was examined by determining the leachability of heavy metals. FAMSS-modified concretes showed small values of water penetration depth (lower than $50 \mathrm{~mm}$ ), as well as good compressive strength (reaching minimum class C30/37 after 130 days of maturing) - similar to the compressive strength obtained for conventional concrete. In addition, the partial replacement of cement with FAMSS has environmental benefits, expressed as a reduction in $\mathrm{CO}_{2}$ emissions. In addition, study has shown that compliance with environmental requirements is associated with heavy metal leaching.
\end{abstract}

Keywords: concrete; sewage sludge combustion; fly ash; compressive strength of concrete; heavy metals leaching

\section{Introduction}

The cement production process can be harmful to the natural environment, emitting large amounts of greenhouse gases due to the high-temperature $\left(1450{ }^{\circ} \mathrm{C}\right)$ process of burning cement clinker and the $\mathrm{CO}_{2}$ emissions resulting from the decarbonization of raw material [1]. Therefore, issues related to improving energy efficiency, protecting the environment and using waste as a raw material are the basic challenges of this industry [2,3].

According to the Yearbook of International Statistics data [4], the production of cement in the world amounted to over 1.67 billion tons in 2000, and 4.07 billion tons in 2013. As a result of this production, in 2000 the cement industry emitted 1.4 billion tons of greenhouse gases (converted to $\mathrm{CO}_{2}$ ) into the atmosphere, which accounted for $3 \%$ of global greenhouse gas emissions and about $5 \%$ of the $\mathrm{CO}_{2}$ emissions resulting from human activities; in 2013, however, cement production increased and amounted to 4.07 billion tons [3-5]. According to Statista (The Statistics Portal for Market Data) [6], global cement production in 2030 is expected to increase to 4.83 billion metric tons. China, India and the United States are among the three major cement producers in the world [6], while Poland is currently the third cement producer in Europe after Germany and Italy. The Central Statistical Office 2019 [7] data shows that, in 2018, cement production in Poland increased by 6\% compared to 2017 and reached 
the level of 18,940 million tones. In 2001, $\mathrm{CO}_{2}$ emissions per 1 ton of clinker were $988 \mathrm{~kg}$ [8]. Thanks to the latest technological solutions, in 2018 the product emission was reduced to $807 \mathrm{~kg} \mathrm{CO}_{2}$ per ton of clinker. However, it is impossible to produce clinker (and therefore also to produce cement) without emissions caused by the decomposition of about $525 \mathrm{~kg} \mathrm{CO}_{2}$ per ton of clinker [9].

In cement technology, and mainly in the concrete technology in Europe, siliceous and calcareous fly ashes from the combustion of black coal and brown coal are widely used [10,11]. Their application in cement composites reduces carbon dioxide emissions and environmental pollution, as well as saves natural resources and fossil fuels [12-20]. It should be noted that the wide application of fly ashes from black coal and brown coal combustion in construction and building materials is mainly determined by the fineness, chemical and mineral composition, as well as pozzolanic activity-similar to cement. At the same time, fly ashes have a beneficial effect on the technical properties of concrete, improving its compressive and bending strengths, and frost resistance [21-23]. These factors make the production of ash concretes attractive to both producers and final consumers [2,24]. Nowadays, sewage sludge created in wastewater treatment plants is a waste with the code 190114 [25], the neutralization and management of which is a serious ecological issue. Sewage sludge combustion is one of the methods of its utilization, whose by-product is fly ash. Research conducted in recent years has been aimed at assessing the possibility of using fly ash from combustion of sewage sludge in concrete technology [12,26-28], and thus increasing waste recycling [26,29]. The physico-chemical properties and pozzolanic activity of fly ashes indicated the potential of this innovative additive $[12,18,26-28,30]$. However, the use of fly ashes as a partial cement substitute increases water demand and reduces the workability and density of concrete mixes [30,31]. Moreover, the use of fly ash from the combustion of sewage sludge in cement composites must be carefully controlled because of its physico-chemical properties, which can vary significantly depending on the type of wastewater entering the treatment plant, as well as on the technology used for sewage sludge processing $[13,32,33]$. The main mineral compounds present in sewage sludge fly ash are quartz $\left(\mathrm{SiO}_{2}\right)$, calcium phosphate $\left(\mathrm{Ca}_{3}(\mathrm{PO} 4)_{2}\right)$, and hematite $\left(\mathrm{Fe}_{2} \mathrm{O}_{3}\right)$, while the main elements are $\mathrm{Si}, \mathrm{Ca}, \mathrm{Fe}, \mathrm{Al}, \mathrm{P}$ and $\mathrm{O}$ [34]. Additionally, the considered fly ashes contain from 10 to $20 \%$ by mass of phosphates [34]. Phosphates can delay cement binding and thus affect the initial strength of concrete. Fly ash from the combustion of sewage sludge may also contain increased sulfate concentrations [35], which are derived from chemicals used in wastewater treatment processes [36].

Fontes et al [17] showed that cement mortars in which cement was replaced with FASS in an amount of $10 \%$ to $30 \%$ showed similar bending strength values to reference mortars. In addition, the partial replacement of cement with fly ash increased the porosity of concrete. Analyzing the results presented in the literature, a differentiated impact of fly ashes on compressive strength values can be noticed. In cement mortars-in which fly ash, together with cements containing a large amount of C3A, was used-no deterioration of compressive strength was observed after 28 days of maturing [37]. Donatello et al. [38] and Pan et al. [37] demonstrated that the replacement of $20 \%$ of Portland cement by fly ash from sewage sludge may result in a reduction in compressive strength of 24 to $52 \%$. Cyr et al. [39] indicated similarly that the compressive and bending strengths after 28 days of curing decreased in comparison to ordinary mortar, while Chen et al. [16] observed a linear negative relationship between the compressive and bending strength of the analyzed mortars and the percentage of cement replacement by fly ashes. In the case of $10 \%$ cement replacement, the decrease in strength was smaller than for the sample with $25 \%$ of fly ash compared to the reference sample. However, in the studies of Monzo et al. [36,40], a moderate increase in the compressive strength of mortars with $15 \%$ sewage sludge ashes compared to comparative mortars was noted. The average increase in strength varied between 8.3-15.3\%. According to Vouk et al. [41], the cement mortar mixtures with a content of fly ashes content up to $20 \%$ revealed similar and higher values of compressive and bending strength compared to reference mixtures depending on fly ash content. According to Baeza-Brotons [35], samples in which cement was exchanged for $5 \%$ of fly ash showed a slightly higher compressive strength, whereas samples with fly ash content above $5 \%$ showed a lower compressive strength than reference sample. However, it should be emphasized that the values of compressive strength were 
higher than $90 \%$ of the values determined for conventional concrete samples. Moreover, Donatello and Cheeseman [42] underlined that, in general, strength parameters may be improved by fly ash milling (grinding). On the other hand, an increase in sewage sludge ashes content causes a decrease in strength.

Taking the variability of physical and chemical composition of fly ash from the combustion of municipal sewage sludge (FAMSS) into consideration, their application can affect the features of concretes manufactured with their addition. The results of the investigations presented in the current paper are a continuation and extension of previous investigations [28]. The paper presents the test results of chemical and physical composition of fly ashes from municipal sewage sludge combustion extracted in the autumn of 2018, and the comparison with the results obtained for the ashes extracted in 2017. In an attempt to recognize the influence of FAMSS on the features of ordinary concretes, and to determine the compressive strength development in time-the concrete mature periods-the percentage share of fly ashes in the mix was extended.

\section{Materials and Methods}

\subsection{Aim and Scope of the Experiment}

The main purpose of the research was to assess the properties of ordinary concretes with a modified composition. The modification consisted of the partial replacement of cement with fly ash from the combustion of municipal sewage sludge. For comparison, experiments were carried out for unmodified concretes and concretes, in which cement was replaced with FAMSS in the range of $5 \%$ to $25 \%$. In addition to the technical properties of analyzed concretes, the leaching of selected substances (including heavy metals), as well as the environmental impact of the produced composites, were determined.

\subsection{Preparation of Concrete Specimens}

Ordinary concrete samples were designed for testing in accordance with PN-EN 206 + A1: 2016-12 "Standard Concrete-Part 1: Requirements, properties, production and compliance" [43]. To perform the tests, concrete mixes of class C20/25 and thick-plastic consistency F2 were designed. The constant grain-size composition of fine aggregates, selected in sieve analysis, as well as of coarse aggregates, selected by consecutive iterations (Table 1), were maintained in all samples. The mix composition was designed using the three equations method of Bukowski [44]. To prepare the concrete samples, a natural aggregate was used with grain size from 0.125 to $16 \mathrm{~mm}$, CEM I 32.5 Portland cement, as well as admixtures. As the mineral admixtures for the concrete mix, fly ashes from the fluidal combustion of municipal sewage sludge in the "Czajka" sewage treatment plant (Warsaw, Poland) were used. The FAMSS tested was produced in May 2018. In order to compare the properties of ordinary concretes produced in the traditional way and concretes containing FAMSS, two types of concrete samples were prepared:

1. Concrete without admixtures-CON,

2. Concrete mixed with fly ashes from combustion of municipal sewage sludge-FAMSS.

Table 1. Percentage content of the aggregates selected by the iterations.

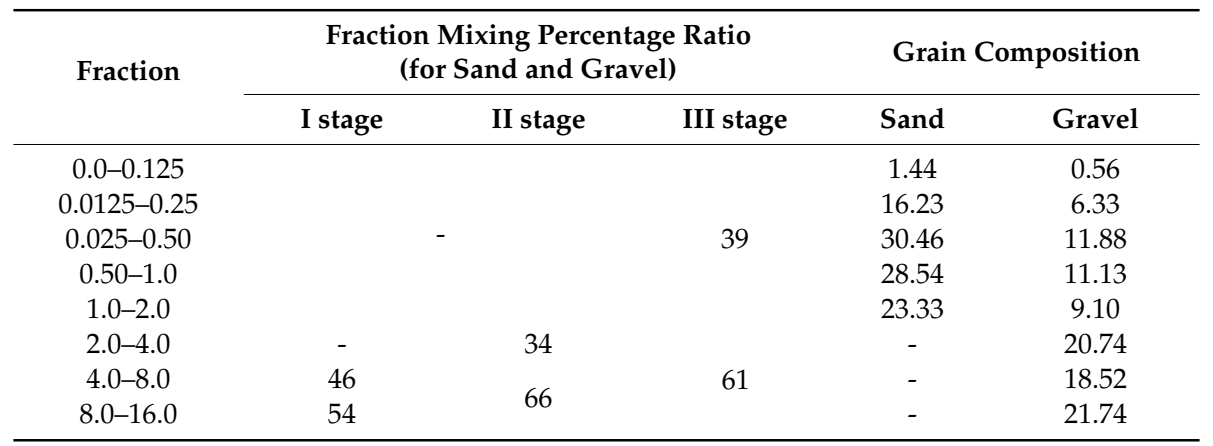


In the individual samples mixed with fly ashes, 5\% (FAMSS 5\%), 10\% (FAMSS 10\%), 15\% (FAMSS $15 \%$ ), $20 \%$ (FAMSS $20 \%$ ) or $25 \%$ (FAMSS $25 \%$ ) of a defined cement mass were replaced by the ashes. The maximum amount of fly ash included in the $k$ value for CEM cement met the condition: fly ash FAMSS/cement $C \leq 0.33$ (by mass). The concrete mix recipe per $1 \mathrm{~m}^{3}$ was established to comply with the assumption of ordinary concrete mix with use of the method of three equations. The proportions of concrete mix tested in the study are shown in Table 2 . After forming, the specimens were cured by immersion in tap water at $18 \pm 2{ }^{\circ} \mathrm{C}[43]$.

Table 2. Concrete mix proportions by weight.

\begin{tabular}{ccccc}
\hline \multirow{2}{*}{ Specification } & \multicolumn{4}{c}{ Mass of Concrete Ingredients $\mathbf{( k g / \mathbf { m } ^ { \mathbf { 3 } } )}$} \\
\cline { 2 - 5 } & Water & Aggregate & Cement & Fly Ash \\
\hline CON & 167.23 & 1885.18 & 376.27 & 0 \\
FAMSS 5\% & 167.23 & 1885.18 & 357.46 & 18.81 \\
FAMSS 10\% & 167.23 & 1885.18 & 338.64 & 37.63 \\
FAMSS 15\% & 167.23 & 1885.18 & 319.83 & 56.44 \\
FAMSS 20 $\%$ & 167.23 & 1885.18 & 301.02 & 75.25 \\
FAMSS 25\% & 167.23 & 1885.18 & 282.20 & 94.07 \\
\hline
\end{tabular}

CEM I 32.5R Portland cement was used in the tests, in all exposure classes excluding classes XA2 and XA3, for which HSR sulphate cements are commonly used. Table 3 presents phase composition and chemical properties, while the physical properties of the FAMSS are presented in Table 4.

Table 3. Chemical and phase composition of CEM I cement [45].

\begin{tabular}{ccc}
\hline Component (unit) & Content & $\begin{array}{c}\text { Content of CEM I Mineral } \\
\text { Phases (mass\%) }\end{array}$ \\
\hline Loss in ignition $(\%)$ & 3.18 & $\mathrm{C}_{3} \mathrm{~S}-61.8$ \\
Sulphate content $\mathrm{SO}_{3}(\%)$ & 3.20 & $\mathrm{C}_{2} \mathrm{~S}-12.3$ \\
Chloride content $\mathrm{Cl}(\%)$ & 0.05 & $\mathrm{C}_{3} \mathrm{~A}-7.5$ \\
Alkali content as $\mathrm{Na}_{2} \mathrm{Oeq}(\%)$ & 0.71 & $\mathrm{C}_{4} \mathrm{AF}-4.0$ \\
\hline & & \\
$\mathrm{N}$ & \\
\hline
\end{tabular}

Table 4. Physical parameters of cement [45].

\begin{tabular}{ccc}
\hline Physical Parameters of Cement & Unit & Average Values \\
\hline Specific surface area according to Blaine & $\left(\mathrm{cm}^{2} / \mathrm{g}\right)$ & 3330 \\
Start of setting time & $(\mathrm{min})$ & 218 \\
Compressive strength after 2 days & $(\mathrm{MPa})$ & 21.0 \\
Compressive strength after 28 days & $(\mathrm{MPa})$ & 49.8 \\
\hline
\end{tabular}

\subsection{Test Methods for Fly Ash}

In order to characterize the physical-chemical properties and activity of FAMSS, and to investigate the possibility of the modification of concretes made with their participation, their chemical composition, mineral composition, grain size and pozzolanicity were examined.

The chemical composition of fly ash was determined on an Epsilon 3 (Panalytical, Almelo, The Netherlands) spectrometer using the X-ray energy dispersion fluorescence (XRF) method. The test was performed in the measuring range of $\mathrm{Na}-\mathrm{Am}$ elements on an apparatus equipped with an $\mathrm{Rh}$ X-ray tube $(9 \mathrm{~W}, 50 \mathrm{kV}, 1 \mathrm{~mA})$, a 4096-channel spectrum analyzer (Panalytical), 6 measuring filters 
(Cu-500, Cu-300, Ti, Al-50, Al-200, Ag) and a high resolution solid state SDD detector (50 $\mu \mathrm{m}$ thick Be window) cooled with a Peltier's cell.

The mineral composition of the fly ashes was determined using powdered X-ray diffraction (XRD) tests with a Panalytical X'pertPRO MPD X-ray diffractometer (Panalytical) with a PW 3020 goniometer (Panalytical). A Cu copper lamp (CuKa $=1.54178 \AA$ ) was used as the source of X-ray emission. X'Pert Highscore software was used to process diffraction data. The identification of mineral phases was based on the PDF-2 Release 2010 database, formalized by JCPDS-ICDD.

The grain size analysis was based on laser diffraction using a Mastersizer 3000 analyzer (Malvern Instruments, Malvern, Worcestershire, UK). The measurement was carried out in a dispersing liquid (demineralized water) in the presence of an ultrasonic probe in order to break up larger aggregates of the tested samples. Grains with equivalent diameter sizes from 0.1 to $1000 \mu \mathrm{m}$ were analyzed. The morphology and chemical composition in the micro area of the main components of the tested materials was determined using the SEM Quanta 250 FEG scanning electron microscope (FEI), equipped with a chemical composition analysis system based on X-ray energy dispersion-EDS (Energy Dispersive X - Ray Spectroscopy, EDAX) [28].

The pozzolanic activity of fly ash was carried out according to PN-EN 450-1: 2012 [46] and the ASTM C379-65TP [47] method as well as guidelines from the literature [48].

\subsection{Test Methods for Concrete Mixes and Concrete}

In order to characterize the properties of the concrete mixes tested, the following tests were carried out: consistency of concrete mixes by the fall cone method [49], bulk density by the mass and volume measurement method [50], and air content by the pressure method [51]. Compressive strength tests were performed according to the guidelines contained in PN-EN 12390-3: 2011 [52] at various curing periods (after 2, 7, 28, 56, 90, 130, and 365 days) on samples of dimensions $150 \mathrm{~mm} \times 150 \mathrm{~mm} \times 150 \mathrm{~mm}$. The compressive strength tests were performed in the H011 Matest hydraulic test machine (Matest, Brembate Sopra, Italy). In the statistical analysis, standard deviation, coefficient of variation and total uncertainty for the recommended confidence interval $p=0.95$ were determined for 6 tested samples. In accordance with the PN-EN ISO/IEC 17025 standard and the ISO procedure adapted for building materials, the unscaled sclerometric method was used to assess the expanded (total) uncertainty $[15,53]$. To test the significance of differences between the compressive strength after selected maturing periods of the reference sample and samples containing FAMSS, a one-way ANOVA variance analysis was performed. The obtained values of compressive strength were adopted as the dependent variable, while the quality factor was the FAMSS content in the individual samples. As part of testing the technical parameters of concrete, the depth of water penetration under pressure was also determined in accordance with EN 12390-8:2019-08 [54]. The test was carried out for 6 samples for each type of concrete after 28 days of maturing. Statistical analyses of the results were performed using Microsoft Excel and Statistica 13.3 software.

Moreover, concrete containing 5, 10, 15, 20 and 25\% of fly ashes as well as the control sample were tested for heavy metals leaching using European standards [55]. Samples of crushed concrete were sieved through $6.3 \mathrm{~mm}$ and $0.63 \mathrm{~mm}$ meshes, and further tests were carried out for fractions smaller than $0.63 \mathrm{~mm}$ and for the fraction of particles between 0.63 and $6.3 \mathrm{~mm}$. Distilled water $(\mathrm{pH}=6.7$, electrical conductivity EC $=0.0270 \mathrm{mS} / \mathrm{cm}$ ) was added to each sample at a 10:1 liquid/solid phase ratio and mixed in a rotary shaker (GFL, Burgwedel, Germany) at $20 \mathrm{rpm}$ for $24 \mathrm{~h}$ at room temperature (21 \pm $2{ }^{\circ} \mathrm{C}$ ). After standing for $30 \mathrm{~min}$, the leachate was filtered through a $0.45 \mathrm{~mm}$ filter paper and analyzed for $(\mathrm{Cd}, \mathrm{Cr}, \mathrm{Cu}, \mathrm{Ni}, \mathrm{Pb}, \mathrm{Zn}, \mathrm{As}$, Se, and $\mathrm{Ba})$ concentrations using the method of inductively coupled plasma atomic emission spectrometry (ICP-AES Thermo Scientific iCAAP 6500 spectrometer, Waltham, MA, USA). Additionally, the concentrations of chlorides and sulphates were determined by titration using chemical reagents and digital burettes (Jencons Digitrate, Bedfordshire, UK) with the accuracy of $\pm 0.01 \mathrm{~mL}$, the concentration of orthophosphate using the colorimetric method with molybdovanadate (DR-6000 spectrophotometer, Hach, Loveland, CO, USA), as well as pH and EC (Eijelkamp 18.50.01 
multimeter, Giesbeek, Nederland), turbidity (by 455 nm, 2100N IS turbidimeter, Hach, USA) and color (DR-6000 spectrophotometer, Hach, USA) of the eluate were determined. Triplicate samples were analyzed $(n=3)$ and their average value was calculated.

\section{Results and Discussion}

\subsection{Properties of Fly Ash and Concrete Mix}

The results of the composition analysis, with additional values of free calcium oxide $\left(\mathrm{CaO}_{\mathrm{F}}\right)$ content, and reactive aluminum, calcium and silica oxides $\left(\mathrm{Al}_{2} \mathrm{O}_{3 \mathrm{R}}, \mathrm{CaO}_{\mathrm{R}}\right.$ and $\mathrm{SiO}_{2 \mathrm{R}}$, respectively) of FAMSS are presented in Figure 1. Silica, phosphorus, aluminum and calcium oxides constituted the largest percentage in the fly ash oxide composition. It was observed that the sum of silica dioxide $\left(25.54 \%\right.$ of $\left.\mathrm{SiO}_{2}\right)$, aluminum oxide $\left(18.98 \%\right.$ of $\left.\mathrm{Al}_{2} \mathrm{O}_{3}\right)$ and iron oxide $\left(7.77 \%\right.$ of $\left.\mathrm{Fe}_{2} \mathrm{O}_{3}\right)$ contents in FAMSS was lower than in conventional ashes, and did not meet the requirements of the PN-EN 450-1 + A1: 2012 standard (minimum 65\% total) [46], which is consistent with the results obtained for FAMSS produced in May 2017 [29]. However, the sum of $\mathrm{SiO}_{2}, \mathrm{Fe}_{2} \mathrm{O}_{3}$ and $\mathrm{Al}_{2} \mathrm{O}_{3}$ contents in FAMSS from 2018 (52.29\%) was higher than in FAMSS from 2017 (35.40\%) tested by Rutkowska et al. [28]. Differences in the chemical composition of the applied ashes can affect the investigated strength properties of the concretes. The chemical components which possibly can affect the improvement of strength properties of the concretes are mainly free $\mathrm{SiO}_{2}$ and $\mathrm{CaO}$. In the ash applied in 2018, their percentage shear was higher than in that used in 2017. However, the strength results presented in this work do not correlate with the results of the chemical composition. In the previous work, the growth in the percentage share from 10 to $15 \%$ did not cause any significant changes in the mechanical strength of the obtained concrete. Nevertheless, the result was ca. $42 \div 46 \mathrm{MPa}$. In this work, the growth in the percentage share caused growth in the mechanical strength. However, the comparable result with the ash from 2017 ( $45 \mathrm{MPa}$ ) was obtained only for the 15\% addition. This is namely the visible difference between the ashes used in both works. This can be evoked by the fact that there is much more $\mathrm{Al}_{2} \mathrm{O}_{3}$ in the ash from 2018 than in that from 2017, which significantly changes the $\mathrm{SiO}_{2} / \mathrm{Al}_{2} \mathrm{O}_{3}$ ratio. In the previous work, this ratio amounted to 1.6 more than the value obtained in 2018 (1.35). The higher $\mathrm{SiO}_{2} / \mathrm{Al}_{2} \mathrm{O}_{3}$ ratio means more free loadings, which possibly positively affect the concrete hydration process. It is the result of replacement of trivalent elements $\left(\mathrm{Al}^{3+}\right)$ by tetravalent ones $\left(\mathrm{Si}^{4+}\right)$.

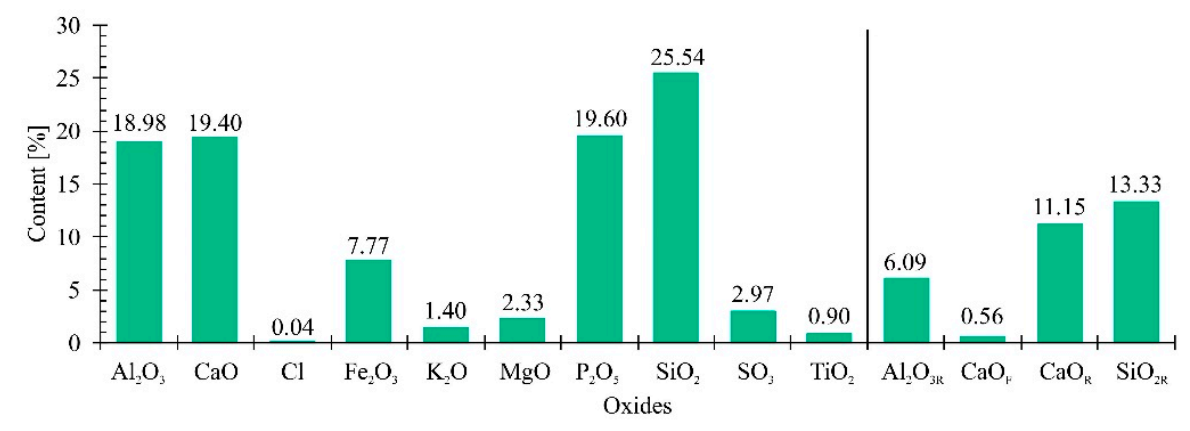

Figure 1. Chemical composition of fly ash from the combustion of municipal sewage sludge (FAMSS) (subscript " $F$ " refers to free oxides and subscript " $R$ " refers to reactive oxides).

Moreover, previously mentioned standards [42] require the content of the reactive $\mathrm{SiO}_{2}$ to be higher than $25 \%$, reactive $\mathrm{CaO}$ lower than $10 \%, \mathrm{MgO}$ lower than $4 \%$, and $\mathrm{Na}_{2} \mathrm{O}$ lower than $5 \%$ by weight. For the tested FAMSS, the content was 13.33, 11.15, 2.33 and $0 \%$, respectively. The set requirements were not met for reactive $\mathrm{SiO}_{2}$ and reactive $\mathrm{CaO}$; the standard applies, however, to siliceous fly ashes obtained during the combustion of coal or co-combustion of coal and waste. In addition, compared to calcareous and siliceous fly ash, it has been noted that FAMSS contains significantly higher amounts of phosphate, which also exceed the required value of a maximum $100 \mathrm{mg} / \mathrm{kg}$ [46]. This is due to phosphorus removal from the wastewater and its accumulation in sewage sludge. It is worth 
emphasizing that these results are consistent with those presented by Tarko et al. [56]. Additionally, the loss of ignition, expressing the content of unburned coal in a given sample of FAMSS sludge, was $0.53 \%$. It is connected with the technology of combustion of municipal sewage in the fluidized bed furnace, and with the combustion temperature exceeding $850{ }^{\circ} \mathrm{C}$.

The particle size distribution of FAMSS tested was monomodal (Figure 2). It can be observed that the maximum particle size was $230 \mu \mathrm{m}$. Particles with a diameter of 2 to $250 \mu \mathrm{m}$ account for $88.82 \%$ by volume. The particle fractions from 50-100 $\mu \mathrm{m}$ and 20-50 $\mu \mathrm{m}$ belonged to fractions with the largest percentage (by volume), and constituted $35.13 \%$ and $23.07 \%$, respectively. For comparison, the particle size distribution of fly ash from another period of operation of the sewage sludge incinerator (May 2017) achieved a maximum value of $100 \mu \mathrm{m}$, and grains with a diameter of 2 to $250 \mu \mathrm{m}$ constituted $91 \%$ of the volume [28]. The tests confirm that the strength parameters of concretes produced on the basis of FAMSS are influenced by the grain size of the additive. The most favorable parameters were obtained with thicker ash particle size used by Rutkowska et al. [28,57]. The specific surface area of the FAMSS was $2560 \mathrm{~cm}^{3} / \mathrm{g}$, while the specific density was $1.826 \mathrm{~kg} / \mathrm{dm}_{3}$. It should be emphasized that, according to Monzo et al. [40], the size of the additive is an important parameter for determining the strength of cement and ash mortars. Larger ash particle sizes cause a decrease in the compressive and tensile strengths of the material. Quartz and anhydrite dominate, with the addition of phosphates in the form of apatite and fluoroapatite, in the mineral composition of fly ashes from the combustion of municipal sewage sludge [58]. Additionally, the SEM images of FAMSS were presented in Figure 3.
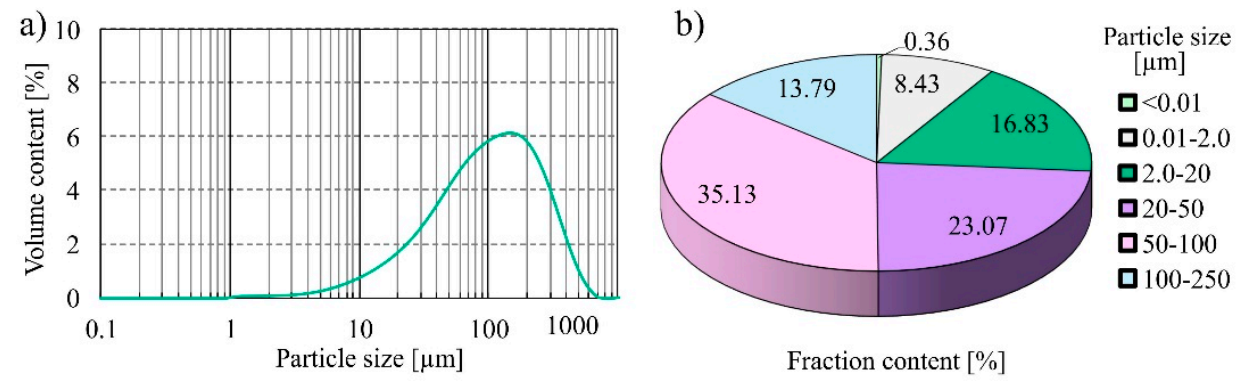

Figure 2. Particle size distribution curve (a) and volume distribution of individual particle fractions (b) in FAMSS.

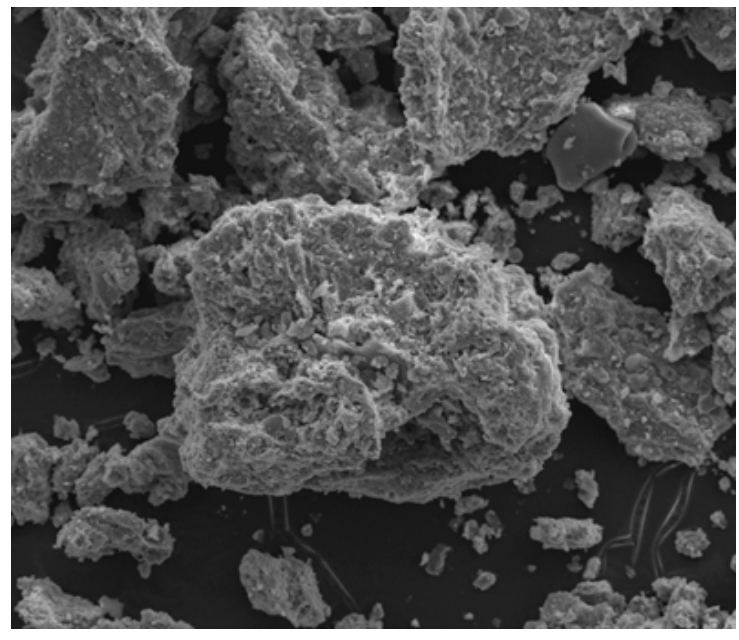

(a)

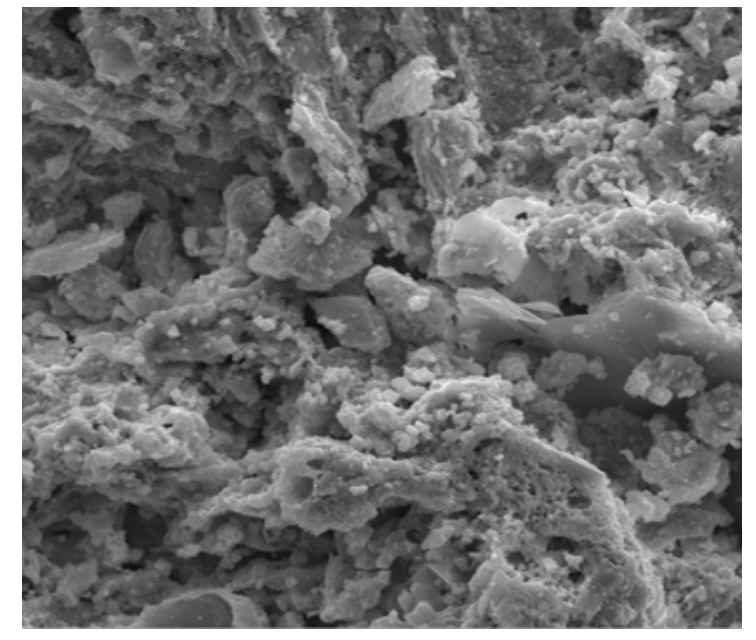

(b)

Figure 3. SEM images of FAMSS: (a) magnification 1000×; (b) magnification 4000×.

The pozzolanic activity of fly ash according to ASTM C379-65T [48] is determined on the basis of the $\mathrm{SiO}_{2}$ and $\mathrm{Al}_{2} \mathrm{O}_{3}$ content. According to the literature, the total content of $\mathrm{SiO}_{2}$ and $\mathrm{Al}_{2} \mathrm{O}_{3}$ above $20 \%$ indicates the pozzolanic character of the tested samples [59]. Based on the investigations, 
it was found that the total content of reactive silica oxide $(13.33 \%)$ and reactive aluminum oxide $(6.09 \%)$ in the FAMSS tested was $19.42 \%$ (Figure 1). The pozzolanic activity desirable of FAMSS after 28 days of curing was $68.5 \%$ (required $\geq 75 \%$ ), while after 90 days it was $79.3 \%$ (required $\geq 85 \%$ ); therefore, FAMSS does not meet the requirements of PN-EN 450-1: 2012 [46]. However, the value of the analyzed parameter exceeded the required values (85\%) after 180 days of curing. It is believed that the phosphorus contained in the fly ashes delays the process of binder hydration [60]. The results obtained in our research confirm those presented by Ferreira et al. [61], Monzo et al. [30] and Merino et al. [31], that the pozzolanic activity of FAMSS reaches the standard value (85\%) after a longer period of curing. Higher values of pozzolanic activity of siliceous fly ash may be determined by the content of alkali in its composition. Potassium oxide plays a major role in this case. According to the literature [48], potassium and aluminum oxide, and thus the $\mathrm{K}_{2} \mathrm{O} / \mathrm{Al}_{2} \mathrm{O}_{3}$ ratio, determine the activity of fly ashes. The content of $\mathrm{K}_{2} \mathrm{O}$ and $\mathrm{Al}_{2} \mathrm{O}_{3}$ in siliceous fly ash tested by Rutkowska et al. [61] was $0.2 \%$ and $27.8 \%$, and in FAMSS it was $1.40 \%$ and $18.98 \%$ (Figure 1), respectively. However, according to Yusuf and Noor [62], the pozzolanic properties and chemical composition (silica, iron, calcium, aluminum) of fly ashes from the combustion of sewage sludge are analogous to the mineral additives that are commonly used. Hubbard and Dhir [48] introduced the pozzolanic potential desirable $\left(\mathrm{K}_{2} \mathrm{O} / \mathrm{Al}_{2} \mathrm{O}_{3} \cdot 10\right)$, which, depending on the proportion of oxides, subdivides fly ashes into three classes. An index of 0.73 was obtained for the FAMSS tested, which classifies the material into medium reactive class (the second class of reactivity).

\subsection{Physical Properties of Concrete Mix and Hardened Concrete}

Based on consistency tests of the concrete mix using the fall cone method for the reference concrete and samples containing $10 \%$ and $15 \%$ of fly ash, a dense plastic consistency was obtained, while for the remaining samples a wet consistency was attained (Table 5). The lowest air content in the reference sample was 3.1\%, while the highest for the FAMSS 25\% sample was 4.6\% (Table 5). An increase in the air content was also observed, along with an increase in the FAMSS content. As specified in PN-EN 206 + A1: 2016-12 [43], concretes with air content above 4\% can be used for exposure class XF (environmental impact-freezing/thawing). The density of the concrete mix attained values from 2319 (FAMSS 25\%) to $2387 \mathrm{~kg} / \mathrm{m}^{3}$ (CON) and was in the range characteristic for ordinary concrete $\left(2000-2600 \mathrm{~kg} / \mathrm{m}^{3}\right)$.

Table 5. Physical properties of the concrete mix.

\begin{tabular}{cccc}
\hline Type of Concrete & Consistency $(\mathbf{m m})$ & Air content $\mathbf{( \% )}$ & Density $\mathbf{( k g / \mathbf { m } ^ { \mathbf { 3 } } )}$ \\
\hline CON & $90(\mathrm{~S} 2)$ & 3.1 & 2387 \\
FAMSS 5\% & $39(\mathrm{~S} 1)$ & 2.8 & 2362 \\
FAMSS 10\% & $67(\mathrm{~S} 2)$ & 3.3 & 2353 \\
FAMSS 15\% & $58(\mathrm{~S} 2)$ & 3.8 & 2338 \\
FAMSS 20\% & $34(\mathrm{~S} 1)$ & 4.1 & 2327 \\
FAMSS 25\% & $27(\mathrm{~S} 1)$ & 4.6 & 2319 \\
\hline
\end{tabular}

According to Monzo et al. [30] and Merino et al. [31], partial replacement of cement with FAMSS reduces the workability of the concrete mix; however, it does not threaten environmental safety. This is due to the fact that the fly ash grains have an irregular structure and high consistency. In addition, based on the analysis of the course of fly ash hydration, it was found that a binder meeting the requirements for cements could be obtained when fly ash replaces $20 \%$ of the mineral components used in the production $[60,63]$. In practical applications, it is recommended to use superplasticizers $[31,60]$. 


\subsection{Mechanical Properties of Concrete}

The average compressive strength at different curing periods with a marked standard deviation and the expanded uncertainty for concrete samples with a variable content of FAMSS is shown in Table 6. The reference concrete samples after two days of curing achieved a compressive strength of $21.92 \mathrm{MPa}$, while the highest value of this parameter equal to $23.22 \mathrm{MPa}$ was observed for FAMSS $20 \%$ (increase by $5.9 \%$ ) and the smallest value equal to 19.01 MPa for FAMSS 5\% (decrease by $13.3 \%$ ). After the next measuring period (7 days of curing), the CON sample achieved a strength of $37.82 \mathrm{MPa}$. The FAMSS 5\% concrete achieved a $29.9 \%$ decrease in strength compared to the reference concrete. The smallest compressive strength after 28 days of curing-equal to $35.61 \mathrm{MPa}$ - was obtained for concrete samples, in which $5 \%$ of cement was replaced with fly ash (FAMSS 5\%), while the highest strength, equal to $42.58 \mathrm{MPa}$, was obtained for concrete samples, in which $20 \%$ of cement was replaced with fly ash (FAMSS 20\%). Compared to the reference concrete, the decrease in the compressive strength of the FAMSS 5\% concrete was $13.9 \%$, while the increase in the FAMSS $20 \%$ concrete was $2.9 \%$. Similar relationships were observed in subsequent curing periods: the lowest compressive strength was obtained for FAMSS 5\% and the highest for FAMSS $20 \%$. The decrease in compressive strength compared to reference concrete was in the range of $11 \%$ to $15 \%$, while the increase was in the range of 1 to $7 \%$. Moreover, it was noticed that all concretes made after 28 days of maturation had the C20/25 concrete class assumed during the design. After 90 days of curing, concrete samples with the lowest ash content (FAMSS 5\%) obtained class C25/30, while the remaining concrete samples were class C30/37. After 365 days of curing, the CON and FAMSS $10 \%, 15 \%$ and $20 \%$ concretes were classified as class C35/45, while concretes with 5 and $25 \%$ ash content were in class C30/37. It should be emphasized that the extension of the maturing period reduced the differences in compressive strength values. Based on the obtained test results, it was found that by replacing cement with FAMSS, it is possible to obtain concretes with compressive strength very similar to the reference concrete. Nevertheless, the partial replacement of cement with FAMSS has environmental benefits, which include a reduction in $\mathrm{CO}_{2}$ emissions (Table 7). Assuming $\mathrm{CO}_{2}$ emissions of $807 \mathrm{~kg}$ per 1 ton of clinker, when replacing $25 \%$ of cement with FAMSS, about $200 \mathrm{~kg}$ less $\mathrm{CO}_{2}$ will be transferred into the atmosphere. Rutkowska et al. [28] proved that the most favorable conditions were obtained with the addition of $10 \%$ of FAMSS (from May 2017) to the concrete mixture. It must be noted that, although the fly ash came from the same installation, it differed in chemical composition and physical properties (e.g., particle size distribution). Moreover, the compressive strength after 28 days of concrete maturing with $10 \%$ of thicker ash from 2017 obtained $43.6 \mathrm{MPa}$-and, after 56 days, obtained 46.2 $\mathrm{MPa}$-whereas with 10\% of ash from 2018 the compressive strengths were $37.8 \mathrm{MPa}$ and 44.62 MPa, respectively. Research presented in the literature $[30,34,60,62,64]$ concerned the impact of fly ash on the strength parameters of concrete and mortar. It was found that replacement of cement with FAMSS up to $15 \%$ had a positive effect on the compressive strength of the concretes produced [56]. However, Monzo et al. [30] proved that mortars containing up to 15\% of ashes show compressive strength comparable to conventional mortars. Moreover, in the case of using additional treatments, such as sample maturation at elevated temperatures or wet ash milling before adding to the mortar, the ash content may be increased to $30 \%$ of the binder mass [30]. Baeza-Brotons et al. [35], however, observed that concrete samples (containing up to $20 \%$ of FAMSS) achieved similar mechanical properties to conventional samples without ash after 28 days of maturation, and that the addition of ash significantly reduced water absorption. Chang et al. [65] in turn showed that the addition of FAMSS in an amount over 10\% reduced the compressive strength of the resulting material. Chen et al. [16] confirmed that both concrete and mortar produced by replacing parts of sand and parts of cement with fly ash in amounts of over $10 \%$, the cement showed less bending and compressive strength compared to materials produced without addition. On the other hand, mortar containing up to $10 \%$ of fly ash had a compressive strength similar to conventional mortar [16]. The coefficient of variation, together with standard deviation, as a measure of dispersion, is used to test the degree of variation in the value of a variable. The highest standard deviation $(2.67 \mathrm{MPa})$ was obtained for a concrete 
sample, in which cement was exchanged with FAMSS in an amount of 5\% (FAMSS 5\%) after 28 days of curing, while the smallest deviation equal $(0.42 \mathrm{MPa})$ was obtained by reference concrete samples $(\mathrm{CON})$. The coefficient of variation ranged from $1.0 \%(\mathrm{CON})$ to $12 \%$ (FAMSS $5 \%$ ). This indicates a low variability of characteristics and homogeneity of the studied population. Furthermore, the quality of the concrete tested is very good. The total uncertainty after 2 days of curing in the tested series at the recommended confidence level $\mathrm{p}=0.95$ was in the range of $1.44 \mathrm{MPa}$ (FAMSS 15\%) to $3.66 \mathrm{MPa}$ (FAMSS 5\%) while, after 7 days, it was in the range of $1.9 \mathrm{MPa}$ (FAMSS 10\%) to $2.95 \mathrm{MPa}$ (FAMSS 25\%). After 28 days, the uncertainty was $1.52 \mathrm{MPa}$ for CON to $4.14 \mathrm{MPa}$ for FAMSS 5\%; after 56 days of curing in the range of $1.86 \mathrm{MPa}$ for FAMSS 10\% to $4.55 \mathrm{MPa}$ for FAMSS 15\%; after 90 days of curing in the range of 2.26 MPa for FAMSS 25\% to $3.73 \mathrm{MPa}$ for FAMSS 5\%; while after a year of curing, in the range of $2.31 \mathrm{MPa}$ for CON to $3.89 \mathrm{MPa}$ for FAMSS $5 \%$.

Table 6. Compressive strength of concrete with FAMSS.

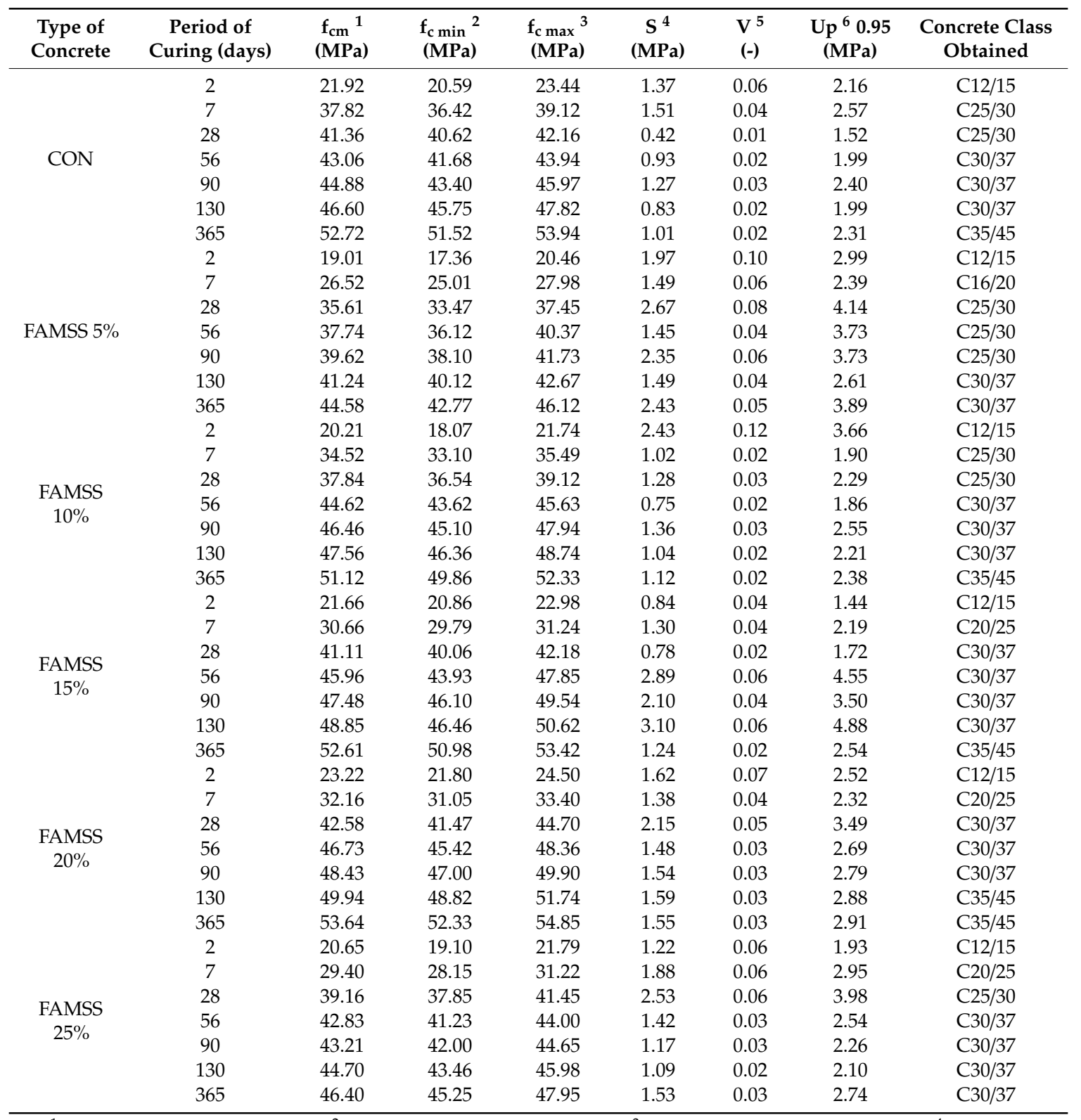

${ }^{1}$ average compressive strength; ${ }^{2}$ minimum compressive strength; ${ }^{3}$ maximum compressive strength; ${ }^{4}$ standard deviation; ${ }^{5}$ coefficient of variation; ${ }^{6}$ total expanded uncertainty for the confidence level $(p=0.95)$. 
Table 7. Impact of FAMSS application on the reduction in $\mathrm{CO}_{2}$ emissions.

\begin{tabular}{|c|c|c|c|c|}
\hline \multirow{2}{*}{ Type of Concrete } & \multicolumn{2}{|c|}{ Mass of Concrete Ingredients $\left(\mathrm{kg} / \mathrm{m}^{3}\right)$} & \multirow{2}{*}{$\begin{array}{c}\mathrm{CO}_{2} \text { Emission } \\
\left(\mathrm{kg} / \mathrm{m}^{3}\right)\end{array}$} & \multirow{2}{*}{$\begin{array}{l}\text { Reduction in } \mathrm{CO}_{2} \\
\text { Emission }\left(\mathrm{kg} / \mathrm{m}^{3}\right)\end{array}$} \\
\hline & Cement & Fly Ash & & \\
\hline $\mathrm{CON}$ & 376.27 & 0 & 303.65 & \\
\hline FAMSS $5 \%$ & 357.46 & 18.81 & 288.47 & 15.18 \\
\hline FAMSS $10 \%$ & 338.64 & 37.63 & 273.28 & 30.37 \\
\hline FAMSS $15 \%$ & 319.83 & 56.44 & 258.10 & 45.55 \\
\hline FAMSS $20 \%$ & 301.02 & 75.25 & 242.92 & 60.73 \\
\hline FAMSS $25 \%$ & 282.20 & 94.07 & 227.74 & 75.91 \\
\hline
\end{tabular}

After the first measurement, i.e., after 2 days of curing, the tested concrete obtained from $39 \%$ (FAMSS 10\%) to $44 \%$ (FAMSS 25\%) - and after 7 days from 58\% (FAMSS 15\%) to $71 \%$ (CON)—of the final strength determined after 365 days of maturation. After the next period of cement maturation (28 days), the reference concrete had $78 \%$ of the final (annual) compressive strength, while in concretes made with FAMSS, the compressive strength accounted for 74-84\% (Figure 4). After 56 days of curing, the reference concrete was characterized by the largest increase in compressive strength. In the interval between 28 and 56 days of curing, the concretes with the addition of fly ash, despite a small increase in strength, had already obtained from 84 to $92 \%$ of the final strength. The obtained test results may indicate the pozzolanic activity of FAMSS. Figure 4 presents the relative changes of compressive strength in relation to maturation period for individual concrete, only for maturing times equal to and longer than 28 days, i.e., for times enabling achieving operational parameters. According to Autors [59,63], the presence of ashes at an amount of $25 \%$ by weight slows the grout setting process and weakens the compressive strength of mortars and concretes in comparison to composites made using only Portland cement. However, faster compressive strength growth was observed in our research for FAMSS $25 \%$ compared to control sampling.

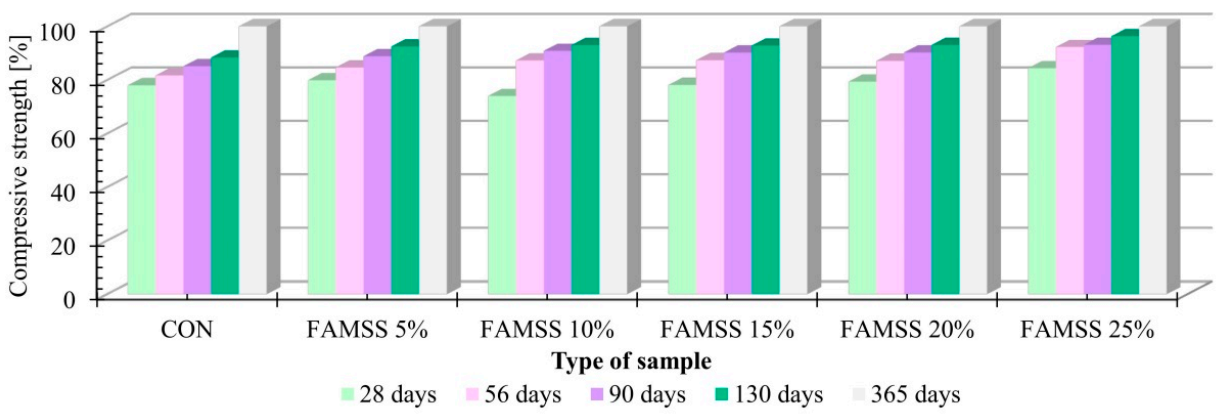

Figure 4. Relative changes in compressive strength.

The results of the analysis of variance (ANOVA) carried out for data obtained for individual maturation periods are presented in Table 8. The obtained values of the significance level p lower than 0.05 indicated the statistical significance of the differences and, therefore, the significant impact of the FAMSS content on the compressive strength of the concrete mixtures.

Table 8. Results of ANOVA analysis of compressive strength at various periods of concrete maturation.

\begin{tabular}{ccccccccc}
\hline $\begin{array}{c}\text { Compressive } \\
\text { Strength After }\end{array}$ & SS Effect & df Effect & MS Effect & SS Error & df Error & MS Error & F & p \\
\hline 2 days & 65.69 & 5 & 13.14 & 39.13 & 30 & 1.30 & 10.07 & 0.000 \\
7 days & 471.92 & 5 & 94.38 & 34.84 & 30 & 1.16 & 81.27 & 0.000 \\
28 days & 200.81 & 5 & 40.16 & 39.13 & 30 & 1.30 & 30.79 & 0.000 \\
56 days & 309.35 & 5 & 61.87 & 43.40 & 30 & 1.45 & 42.77 & 0.000 \\
90 days & 313.25 & 5 & 62.65 & 38.88 & 30 & 1.30 & 48.34 & 0.000 \\
130 days & 296.37 & 5 & 59.27 & 38.94 & 30 & 1.30 & 45.66 & 0.000 \\
365 days & 417.74 & 5 & 83.55 & 39.52 & 30 & 1.32 & 63.43 & 0.000 \\
\hline
\end{tabular}


Based on the conducted tests of the depth of water penetration under pressure, a decreasing depth was observed along with the increase in the percentage of FAMSS (Table 9). According to the EN 12390-8:2019-08 [54] standard, concrete is defined as waterproof when the maximum depth of water penetration under pressure measured at the fractures of tested samples is less than $50 \mathrm{~mm}$. The samples of reference concrete $(\mathrm{CON})$ obtained the largest depth of water penetration, equal to $25.2 \mathrm{~mm}$. The concrete samples with the addition of FAMSS reached values from $12.6 \mathrm{~mm}$ (FAMSS $25 \%$ ) to $20.7 \mathrm{~mm}$ (FAMSS 5\%). The water penetration depth did not exceed $50 \mathrm{~mm}$ in any sample tested, which should be considered a satisfactory result. The coefficient of variation ranged from $7 \%(\mathrm{CON})$ to $11 \%$ (FAMSS 15\% and FAMSS 20\%). The smallest standard deviation (1.04 mm) was obtained for a concrete sample, in which cement was exchanged with FAMSS in an amount of 25\% (FAMSS 25\%), while the highest deviation equal $(1.97 \mathrm{~mm})$ was obtained by the sample FAMSS $10 \%$. This indicates the low variability of characteristics and homogeneity of the studied population.

Table 9. Depth of water penetration under pressure.

\begin{tabular}{ccccccc}
\hline \multirow{2}{*}{ Parameter } & \multicolumn{7}{c}{ Type of Concrete } \\
\cline { 2 - 7 } & CON & FAMSS 5\% & FAMSS 10\% & FAMSS 15\% & FAMSS 20\% & FAMSS 25\% \\
\hline Depth of water & 25.2 & 20.7 & 19.6 & 15.8 & 13.8 & 12.6 \\
penetration (mm) & 1.7 & 1.92 & 1.97 & 1.80 & 1.57 & 1.04 \\
Standard deviation (mm) & 0.07 & 0.09 & 0.10 & 0.11 & 0.11 & 0.08 \\
Coefficient of variation (-) & 0.97 &
\end{tabular}

\subsection{Leachability}

The chemical and physical characteristic of eluates from the crushed concrete samples is presented in Table 10. The $\mathrm{pH}$ of the eluates indicates a tendency for the value of this parameter (in the range of $11.91 \pm 0.04$ to $12.32 \pm 0.05$ ) to decrease with rising proportion of FAMSS in the cement mix. It may be influenced by the $\mathrm{pH}$ of FAMSS itself, which was $9.75 \pm 0.08$ [28]. However, no difference in the $\mathrm{pH}$ between the particle fractions was observed for all the tested concrete mixes. That relationship was observed for electrical conductivity; higher EC values of the eluate were observed for the particle fractions smaller than $0.63 \mathrm{~mm}$. A significant decrease in the value of this parameter was also observed, along with the increasing content of FAMSS. Based on the test results obtained, it is not possible to clearly determine the impact of the percentage of FAMSS and the fraction of crushed concrete on the color and turbidity of the eluate.

Table 10. Chemical and physical parameters of eluates.

\begin{tabular}{|c|c|c|c|c|c|c|c|c|}
\hline $\begin{array}{l}\text { Type of } \\
\text { Concrete }\end{array}$ & $\begin{array}{l}\text { Fraction } \\
(\mathrm{mm})\end{array}$ & $\mathrm{pH}$ & $\mathrm{EC}(\mathrm{mS} / \mathrm{cm})$ & $\begin{array}{c}\text { Color } \\
(\mathrm{mgPt})\end{array}$ & $\begin{array}{c}\text { Turbidity } \\
\text { (NTU) }\end{array}$ & $\begin{array}{c}\mathrm{PO}_{4} \\
(\mathrm{mg} / \mathrm{L})\end{array}$ & $\begin{array}{c}\mathrm{SO}_{4} \\
(\mathrm{mg} / \mathrm{L})\end{array}$ & $\begin{array}{c}\mathrm{Cl} \\
(\mathrm{mg} / \mathrm{L})\end{array}$ \\
\hline \multirow[t]{2}{*}{$\mathrm{CON}$} & $<0.63$ & $12.30 \pm 0.08$ & $8.43 \pm 0.23$ & $24 \pm 15.5$ & $4.02 \pm 0.42$ & $0.10 \pm 0.00$ & nd & $17.7 \pm 1.4$ \\
\hline & $0.63-6.3$ & $12.26 \pm 0.11$ & $7.55 \pm 0.46$ & $22 \pm 11.3$ & $3.55 \pm 0.17$ & $0.05 \pm 0.07$ & nd & $14.9 \pm 1.2$ \\
\hline \multirow{2}{*}{ FAMSS 5\% } & $<0.63$ & $12.28 \pm 0.03$ & $9.17 \pm 0.11$ & $23.5 \pm 4.5$ & $2.87 \pm 0.96$ & $0.10 \pm 0.14$ & nd & $34.0 \pm 2.0$ \\
\hline & $0.63-6.3$ & $12.27 \pm 0.04$ & $7.13 \pm 0.76$ & $20.5 \pm 0.7$ & $2.05 \pm 0.10$ & $0.10 \pm 0.14$ & nd & $32.6 \pm 1.7$ \\
\hline \multirow{2}{*}{ FAMSS 10\% } & $<0.63$ & $12.32 \pm 0.05$ & $8.05 \pm 0.39$ & $32 \pm 2.8$ & $3.95 \pm 2.34$ & $0.30 \pm 0.07$ & nd & $32.6 \pm 1.5$ \\
\hline & $0.63-6.3$ & $12.24 \pm 0.03$ & $7.63 \pm 0.55$ & $24.5 \pm 2.1$ & $6.68 \pm 5.69$ & $0.20 \pm 0.00$ & nd & $29.8 \pm 1.7$ \\
\hline \multirow{2}{*}{ FAMSS 15\% } & $<0.63$ & $12.22 \pm 0.04$ & $8.82 \pm 0.16$ & $25.5 \pm 13.4$ & $3.99 \pm 3.13$ & $0.30 \pm 0.07$ & nd & $26.9 \pm 1.3$ \\
\hline & $0.63-6.3$ & $12.13 \pm 0.04$ & $7.56 \pm 0.12$ & $25.5 \pm 16.2$ & $3.98 \pm 2.77$ & $0.15 \pm 0.07$ & nd & $25.8 \pm 1.5$ \\
\hline \multirow{2}{*}{ FAMSS 20\% } & $<0.63$ & $12.10 \pm 0.03$ & $3.16 \pm 0.12$ & $22 \pm 5.7$ & $3.05 \pm 1.07$ & $0.25 \pm 0.07$ & nd & $19.9 \pm 1.3$ \\
\hline & $0.63-6.3$ & $12.01 \pm 0.05$ & $3.54 \pm 0.02$ & $24.5 \pm 3.5$ & $3.86 \pm 1.78$ & $0.20 \pm 0.07$ & $1 \pm 0.97$ & $15.6 \pm 1.4$ \\
\hline \multirow{2}{*}{ FAMSS 25\% } & $<0.63$ & $11.99 \pm 0.04$ & $3.69 \pm 0.62$ & $27 \pm 8.5$ & $6.35 \pm 5.42$ & $0.35 \pm 0.21$ & nd & $21.3 \pm 1.1$ \\
\hline & $0.63-6.3$ & $11.91 \pm 0.04$ & $3.15 \pm 0.84$ & $40.5 \pm 9.2$ & $9.38 \pm 1.26$ & $0.5 \pm 0.14$ & $10 \pm 1.2$ & $18.4 \pm 1.2$ \\
\hline
\end{tabular}

Studies have confirmed the assumption that the addition of FAMSS increases the leaching of phosphorus compounds (orthophosphates) relative to reference concrete (Table 10). It was also observed that for concrete samples containing from 10 to $20 \%$ of FAMSS, leaching of $\mathrm{PO}_{4}$ was higher for particle fractions smaller than $0.63 \mathrm{~mm}$. It could be due to the larger contact surface of distilled water 
with the tested material. The concentration of sulfates in the eluate was only higher than the detection limit of the method for concrete samples with a grain size of $0.63-6.3 \mathrm{~mm}$, containing $20 \%$ and $25 \%$ of FAMSS. The test results indicated an inverse relationship between the chloride leaching rate and the FAMSS content in concrete, but only in the range of $5 \%$ to $20 \%$ of FAMSS. Further increase in fly ash content caused a slight increase in chloride leaching. However, the addition of FAMSS increased the chloride concentration in the eluate in relation to the reference concrete. It should be emphasized that even the highest concentration of $\mathrm{Cl}$ in the eluate observed ( $34 \mathrm{mg} / \mathrm{L}$ ) was lower than the values obtained by [28] for concretes containing conventional siliceous and calcareous ashes.

For all analyzed samples, the concentration of $\mathrm{As}, \mathrm{Cd}, \mathrm{Ni}, \mathrm{Pb}$ and $\mathrm{Se}$ in the eluates was lower than the detection limit (Table 11). The barium concentration increased with the FAMSS content in concrete and with the grinding of concrete. The largest differences between fine $(0.63 \mathrm{~mm})$ and coarse fractions (0.63-6.3 mm) were observed for FAMSS 20\% and FAMSS 25\%. Chromium was reported in samples containing $5 \%$ to $15 \%$ FAMSS; for the control sample and for concretes containing $20 \%$ and $25 \%$ of ash, the $\mathrm{Cr}$ concentration was lower than the detection limit. The grain size of the crushed concrete had no significant effect on the degree of leaching of this metal. Copper was washed out from all samples, including the control sample. The $\mathrm{Cu}$ concentration decreased with the ash content; however, for FAMSS 5\% and FAMSS 10\% samples with particles of $<0.63 \mathrm{~mm}$, the Cu concentration was higher than for reference concrete. Compared to the results of the research presented by Rutkowska et al. [28], the concentrations obtained for FAMSS 15\% were lower for $\mathrm{SO}_{4}, \mathrm{Cl}$ and $\mathrm{Ba}$ and higher for $\mathrm{Cu}$ and $\mathrm{Cr}$. Moreover, leachability tests confirmed the lack of stability of fly ash properties produced in the same municipal sewage sludge processing installation. According to Jiao et al. [65], the leaching of heavy metals from FAMSS is controlled by several processes, e.g., the leaching of $\mathrm{Cr}$ and $\mathrm{Cd}$ is influenced by their dissolution, and the leaching of $\mathrm{Pb}, \mathrm{Zn}$ and $\mathrm{Cu}$ by precipitation and sorption processes.

Table 11. Heavy metals concentration in eluates.

\begin{tabular}{|c|c|c|c|c|c|c|c|c|c|c|}
\hline \multirow{2}{*}{ Sample } & \multicolumn{10}{|c|}{ Heavy Metals (m/L) } \\
\hline & As & $\mathbf{B a}$ & $\mathrm{Cd}$ & $\mathrm{Cr}$ & $\mathrm{Cu}$ & $\mathrm{Ni}$ & $\mathrm{Pb}$ & Se & $\mathrm{Zn}$ & $\Sigma \mathrm{HM}$ \\
\hline \multicolumn{11}{|l|}{$\mathrm{CON}$} \\
\hline$<0.63$ & $<0.010$ & 0,447 & $<0.002$ & $<0.010$ & 0.043 & $<0.005$ & $<0.003$ & $<0.010$ & $<0.030$ & $<0.086$ \\
\hline $0.63-6.3$ & $<0.010$ & 0,371 & $<0.002$ & $<0.010$ & 0.040 & $<0.005$ & $<0.003$ & $<0.010$ & $<0.030$ & $<0.083$ \\
\hline \multicolumn{11}{|l|}{ FAMSS $5 \%$} \\
\hline$<0.63$ & $<0.010$ & 0,601 & $<0.002$ & 0.038 & 0.048 & $<0.005$ & $<0.003$ & $<0.010$ & $<0.030$ & $<0.119$ \\
\hline $0.63-6.3$ & $<0.010$ & 0,363 & $<0.002$ & 0.034 & 0.033 & $<0.005$ & $<0.003$ & $<0.010$ & $<0.030$ & $<0.100$ \\
\hline \multicolumn{11}{|l|}{ FAMSS $10 \%$} \\
\hline$<0.63$ & $<0.010$ & 0,659 & $<0.002$ & 0.038 & 0.046 & $<0.005$ & $<0.003$ & $<0.010$ & $<0.030$ & $<0.117$ \\
\hline $0.63-6.3$ & $<0.010$ & 0,421 & $<0.002$ & 0.036 & 0.032 & $<0.005$ & $<0.003$ & $<0.010$ & $<0.030$ & $<0.101$ \\
\hline \multicolumn{11}{|l|}{ FAMSS $15 \%$} \\
\hline$<0.63$ & $<0.010$ & 0,660 & $<0.002$ & 0.039 & 0.035 & $<0.005$ & $<0.003$ & $<0.010$ & $<0.030$ & $<0.107$ \\
\hline $0.63-6.3$ & $<0.010$ & 0,507 & $<0.002$ & 0.033 & 0.036 & $<0.005$ & $<0.003$ & $<0.010$ & $<0.030$ & $<0.102$ \\
\hline \multicolumn{11}{|c|}{ FAMSS $20 \%$} \\
\hline$<0.63$ & $<0.010$ & 1.37 & $<0.002$ & $<0.010$ & 0.027 & $<0.005$ & $<0.003$ & $<0.010$ & $<0.030$ & $<1.440$ \\
\hline $0.63-6.3$ & $<0.010$ & 0.421 & $<0.002$ & $<0.010$ & 0.019 & $<0.005$ & $<0.003$ & $<0.010$ & 0.044 & $<0.524$ \\
\hline \multicolumn{11}{|l|}{ FAMSS $25 \%$} \\
\hline$<0.63$ & $<0.010$ & 1.44 & $<0.002$ & $<0.010$ & 0.029 & $<0.005$ & $<0.003$ & $<0.010$ & $<0.030$ & $<1.512$ \\
\hline $0.63-6.3$ & $<0.010$ & 0.146 & $<0.002$ & $<0.010$ & 0.011 & $<0.005$ & $<0.003$ & $<0.010$ & $<0.030$ & $<0.200$ \\
\hline
\end{tabular}

In summary, it should be noted that the ashes studied are environmentally safe, because the sum of heavy metals washed out from concrete containing up to $25 \%$ FAMSS is less than $1.512 \mathrm{mg} / \mathrm{L}$ (the maximum permissible value is $10 \mathrm{mg} / \mathrm{L}$ ). The concentration of $\mathrm{Mo}, \mathrm{Hg}$ and $\mathrm{Sb}$ was not included in this value; however, according to previous studies for FAMSS [28], their concentration was below the limit of detection. Moreover, metal concentrations in the eluate did not exceed the limit values for inert waste. The achieved research results are consistent with the results obtained by other research centers. Previous research taken up on the topic $[13,16,18,20]$ has concentrated on the using possibilities of fly ashes for construction purposes, taking into account both environmental and technical criteria. It should 
also be emphasized that at any stage of their application, there must be no risk to people employed in working with waste and users, and—additionally—-these activities should be economically profitable.

\section{Conclusions}

Fly ashes are a very important additive modifying ordinary concrete and new generation concrete. However, when considering the use of fly ashes in concrete production, the physico-chemical composition, fineness and pozzolanic activity of the additives should be taken into account. Based on the presented research, the assessment of concrete modification with fly ash from the combustion of municipal sewage sludge was carried out and the following conclusions can be drawn:

1. The addition of the analyzed fly ashes in amounts up to $25 \%$ by mass does not cause the deterioration of compressive strength of concrete in relation to reference concrete. The best strength parameters compared to the reference concrete were obtained for samples containing $10 \%$ to $20 \%$ FAMSS.

2. The maturation time of the produced composites had a significant impact on the obtained results. The slow increase in the strength of concrete containing FAMSS could be caused by the presence of phosphorus delaying the cement hydration process.

3. All concretes obtained the same class of C30/37 and higher C35/45 (FAMSS 20\%) after 130 days of maturing, while the reference concrete (CON) and concretes with FAMSS in the amount of $10 \%$ (FAMSS 10\%), 15\% (FAMSS 15\%) and 20\% (FAMSS 20\%) after 365 days of maturing achieved an even higher class of C35/45.

4. The depth of water penetration under pressure for all samples was less than $30 \mathrm{~mm}$, which met standard requirements.

5. The pozzolanic activity of FAMSS did not meet the applicable requirements after 28 days $(\geq 75 \%)$ and 90 days $(\geq 85 \%)$ of curing. FAMSS reached the required values of pozzolanic activity $(85 \%)$ after a longer period of curing, which allowed it to be classified as active mineral additives.

6. Calcium, silica, phosphorus and aluminum oxide are the largest percentage of oxides in FAMSS samples. The sum of silica oxide, aluminum and iron oxides content does not meet the requirements contained in existing standards. However, there are no regulations regarding the physical and chemical properties of fly ashes from combustion of municipal sewage sludge.

7. Based on the sum of heavy metals leached and the concentration of individual heavy metals concentration in the eluate it may be concluded that concrete containing FAMSS in the range of $5 \%$ to $25 \%$ is environmentally safe. However, studies of the physical and chemical properties of FAMSS have shown their variability in time. Therefore, further research on the impact of this variability on the technical parameters of concretes containing FAMSS seems necessary.

Author Contributions: Conceptualization, G.R., P.W. and J.F.; data curation, G.R. and J.F.; investigation, G.R., M.M., M.F. and J.F.; methodology, G.R. and J.F.; supervision, G.R. and J.F.; visualization, G.R., P.W. and J.F.; writing-original draft, G.R.; writing-review and editing, P.W. and J.F. All authors have read and agreed to the published version of the manuscript.

Funding: This research was funded by EU, grant number POIR.04.04.00-00-0004/15.

Acknowledgments: The authors would like to thank the "Czajka" sewage treatment plant for access to fly ashes from combustion of sewage sludge.

Conflicts of Interest: The authors declare no conflict of interest.

\section{References and Notes}

1. Markiv, T.; Sobol, K.; Franus, M.; Franus, W. Mechanical and durability properties of concretes incorporating natural zeolite. Arch. Civ. Mech. Eng. 2016, 16, 554-562. [CrossRef]

2. Topcu, I.B.; Saridemir, M. Prediction of compressive strength of concrete containing fly ash using artificial neural networks and fuzzy logic. Comput. Mater. Sci. 2008, 41, 305. [CrossRef] 
3. Uliasz-Bocheńczyk, A.; Deja, J. CCS technology for the cement industry. Sci. Works Inst. Ceram. Build. Mater. 2012, 11, 136-143.

4. Statistics Poland. International Statistics Yearbook; GUS: Warsaw, Poland, 2015.

5. IEA Greenhouse Gas R\&D Programme (IEA GHG). $\mathrm{CO}_{2}$ Capture in the Cement Industry; Technical Report; IEA GHG: Cheltenham, UK, July 2008.

6. The Statistics Portal for Market Data. Available online: https://www.statista.com (accessed on 23 September 2019).

7. Statistics Poland. Statistical Yearbook of Industry 2018 - Poland; GUS: Warsaw, Poland, 2018.

8. Statistics Poland. Statistical Yearbook of Industry 2002 - Poland; GUS: Warsaw, Poland, 2002.

9. Cement Producers Association SPC. Available online: https://www.polskicement.pl/ (accessed on 5 July 2019).

10. Deja, J.; Antosiak, B. Degree of progress of the fly ash reaction in alkali-activated fly-ash binders. Cem. Lime Concr. 2012, 2, 67-76.

11. Dziuk, D.; Giergiczny, Z.; Garbacik, A. Calcareous fly ash as a main constituent of common cements. Roads Bridges 2013, 12, 57-69.

12. Chen, Z.; Poon, C.S. Comparative studies on the effects of sewage sludge ash and fly ash on cement hydration and properties of cement mortars. Constr. Build. Mater. 2017, 154, 791-803. [CrossRef]

13. Yadav, S.; Agnihotri, S.; Gupta, S.; Tripathi, R.K. Incorporation of STP Sludge and Fly ash in Brick Manufacturing: An attempt to save the Environment. Int. J. Adv. Res. Technol. 2014, 3, 138-144. [CrossRef]

14. Wichowski, P.; Rutkowska, G.; Nowak, P. Elution of selected heavy metals from concretes containing ashes produced in thermal conversion of sludge. Acta Sci. Pol. Architectura 2017, 16, 43-51.

15. Brunarski, L.; Dohojda, M. Approach of concrete compressive strength in situ. Bull. Pol. Acad. Technol. 2016, 64, 687-695. [CrossRef]

16. Chen, M.; Blanc, D.; Gautier, M.; Mehu, J.; Gourdon, R. Environmental and technical assessments of the potential utilization of sewage sludge ashes (SSAs) as secondary raw materials in construction. Waste Manag. 2013, 33, 1268-1275. [CrossRef]

17. Fontes, C.M.A.; Barbosa, M.C.; Toledo Filho, R.D.; Goncalves, J.P. Potentiality of sewage sludge ash as mineral additive in cement mortar and high performance concrete. In Proceedings of the International RILEM Conference on the Use of Recycled Materials in Buildings and Structures, Barcelona, Spain, 8-11 November 2004; pp. 797-806.

18. Wang, L.S.G.; Hustad, J.E.; Gronil, M.G. Sintering characteristics of sewage sludge ashes at elevated temperatures. Fuel Process. Technol. 2012, 96, 88-97. [CrossRef]

19. Weng, C.H.; Lind, F.; Chiang, P.C. Utilization of sludge as brick materials. Adv. Environ. Res. 2003, 7, $679-685$. [CrossRef]

20. Yenc, L.; Tseng, D.H.; Lin, T.T. Characterization of eco-cement paste produced from waste sludges. Chemosphere 2011, 84, 220-226.

21. Gupta, S.M. Support vector machines based modelling of concrete strength. Eng. Technol. Word Acad. Sci. 2007, 36, 305-311.

22. Kim, J.I.; Kim, D.K. Application of neural networks for estimation of concrete strength. KSCE J. Civ. Eng. 2002, 6, 429-438. [CrossRef]

23. Lai, S.; Serra, M. Concrete strength prediction by means of neural network. Constr. Build. Mater. 1997, 11, 93-98. [CrossRef]

24. Saridemir, M. Prediction of compressive strength of concretes containing metakaolin and silica fume by artificial neural networks. Adv. Eng. Softw. 2009, 40, 350-355. [CrossRef]

25. EU/2014/955 Commission Decision of 18 December 2014 amending Decision 2000/532/EC on the list of waste pursuant to Directive 2008/98/EC of the European Parliament and of the Council. Off. J. 2014, L370, 44-86.

26. Chen, Z.; Li, J.S.; Poon, C.S. Combined use of sewage sludge ash and recycled glass cullet for the production of concrete blocks. J. Clean. Prod. 2018, 171, 1447-1459. [CrossRef]

27. Lynn, C.J.; Dhir, R.K.; Ghataora, G.S.; West, R.P. Sewage sludge ash characteristics and potential for use in concrete. Constr. Build. Mater. 2015, 98, 767-779. [CrossRef]

28. Rutkowska, G.; Wichowski, P.; Fronczyk, J.; Franus, M.; Chalecki, M. Use of fly ashes from municipal sewage sludge combustion in production of ash concretes. Constr. Build. Mater. 2018, 188, 874-883. [CrossRef]

29. Franus, M.; Józefaciuk, G.; Bandura, L.; Lamorski, K.; Hajnos, M.; Franus, W. Modification of Lightweight Aggregates' Microstructure by Used Motor Oil Addition. Materials 2016, 9, 845. [CrossRef] 
30. Monzó, J.; Paya, J.; Borrachero, M.V.; Girbes, I. Reuse of sewage sludge ashes (SSA) in cement mixtures: The effect of SSA on the workability of cement mortars. Waste Manag. 2003, 23, 373-381. [CrossRef]

31. Merino, J.; Arevalo, L.F.; Romero, F. Characterization and possible uses of ashes from wastewater treatment plants. Waste Manag. 2005, 25, 1046-1054. [CrossRef]

32. Lopes, M.H.; Abelha, P.; Lapa, N.; Oliveira, J.S.; Cabrita, I.; Gulyurtlu, I. The behaviour of ashes and heavy metals during co-combustion of sewage sludges in a fluidized bed. Waste Manag. 2013, 23, 859-870. [CrossRef]

33. Vouk, D.; Nakic, D.; Stirmer, N.; Malus, D. Possibilities for recycling of sewage sludge. In Proceedings of the 14th International Symposium Water Management and Hydraulic Engineering, Brno, Czech Republic, 8-10 September 2015; pp. 219-228.

34. Perez-Carrion, M.; Baeza-Brotons, F.; Paya, J.; Saval, J.M.; Zornoza, E.; Borrachero, M.V.; Garces, P. Potential use of sewage sludge ash (SSA) as a cement replacement in precast concrete blocks. Mater. Construcc. 2014, 64, 313. [CrossRef]

35. Baeza-Brotons, F.; Garces, P.; Paya, J.; Saval, J.M. Portland cement systems with addition of sewage sludge ash. Application in concretes for the manufacture of blocks. J. Clean. Prod. 2014, 82, 112-124. [CrossRef]

36. Monzo, J.; Paya, J.; Borrachero, M.V.; Bellver, A.; Peris-Mora, E. Study of cement-based mortars containing spanish ground sewage sludge ash. Stud. Environ. Sci. 1997, 71, 349-354.

37. Pan, S.C.; Tseng, D.H.; Lee, C.C.; Lee, C. Influence of the fineness of sewage sludge ash on the mortar properties. Waste Manag. 2003, 33, 1749-1754. [CrossRef]

38. Donatello, S.; Tyrer, M.; Cheeseman, C.R. EU landfill acceptance criteria and EU Hazardous Waste Directive compliance testing of incinerated sewage sludge ash. Waste Manag. 2010, 30, 63-71. [CrossRef]

39. Cyr, M.; Coutand, M.; Clastres, P. Technological and environmental behaviour of sewage sludge ash (SSA) in cement-based materials. Cem. Concr. Res. 2007, 37, 1278-1289. [CrossRef]

40. Monzó, J.; Paya, J.; Borrachero, M.V.; Peris-Mora, E. Mechanical behaviour of mortars containing sewage sludge ash (SSA) and Portland cements with different tricalcium aluminate content. Cem. Concr. Res. 1999, 29, 87-94. [CrossRef]

41. Vouk, D.; Nakic, D.; Stirmer, N. Reuse of sewage sludge-Problems and possibilities. In Proceedings of the International Conference IWWATV 2015, Athens, Greece, 21-23 May 2015; Available online: http: //iwwatv.uest.gr/proceedings/pdf/Vouk_et_al.pd (accessed on 28 August 2019).

42. Donatello, S.; Cheeseman, C.R. Recycling and recovery routes for incinerated sewage sludge ash (SSA): A review. Waste Manag. 2013, 33, 2328-2340. [CrossRef] [PubMed]

43. EN 206+A1:2016-12 Concrete. Part 1. Requirements, Properties, Manufacturing and Conformity.

44. Jamroży, Z. Concrete and Its Technologirs, 3rd ed.; PWN: Warsaw, Poland, 2015. (In Polish)

45. A CRH Company, Karsy 77, 27-530 Ożarów, Poland. Unpublished data from the cement producer.

46. EN 450-1: 2012 Fly-ashes for concrete. Part1: Definitions, specifications and conformity criteria.

47. ASTM C379-65T-Specification for fly ash for use as a pozzolanic material with lime.

48. Hubbard, F.H.; Dhir, R.K. A compositional index of the pozzolanic potential of pulverized-fuel ash. J. Mater. Sci. 1984, 3, 958-960. [CrossRef]

49. EN 12350-2: 2011 Testing of fresh concrete. Part 2: Slump test.

50. EN 12350-6: 2011 Testing of fresh concrete. Part 6: Density.

51. EN 12350-7: 2011 Testing of fresh concrete. Part 7: Air content - pressure method.

52. EN 12390-3: 2011 Testing of hardened concrete. Part 3. Compressive strength of test specimens.

53. EN ISO/IEC 17025:20018-02. General requirements for the competence of testing and calibration laboratories.

54. EN 12390-8: 2019-08 Testing concrete. Part 8: Depth of water penetration under pressure.

55. EN 12457-2: 2006. Characterization of waste. Leaching-Compliance test for leaching of granular waste materials and sludges. Part 2: One stage batch test at a liquid to solid ratio of $10 \mathrm{l} / \mathrm{kg}$ for materials with particle size below $4 \mathrm{~mm}$ (without or with size reduction).

56. Tarko, B.; Gorazda, K.; Wzorek, Z.; Nowak, A.K.; Kowalski, Z.; Kulczycka, J.; Henclik, A. Recovery of phosphorus from industrial sewage sludge ashes. Chem. Ind. 2014, 93, 1041-1044.

57. Rutkowska, G.; Świgoń, K. How are parameters of an ordinary concrete affected by ashes generated in thermal treatment of wastewater sediments and used as a substitute of a part of the cement. Acta Sci. Pol. Architectura 2019, 18, 47-57. (In Polish) 
58. Rutkowska, G. Concrete Modified by Fly-Ashes from Thermal Conversion of Sewage Sludge; SGGW: Warsaw, Poland, 2019. (In Polish)

59. Ferreira, C.; Ribeiro, A.; Ottosen, L. Possible applications for municipal solid waste fly ash. J. Hazard. Mater. 2003, 96, 201-216. [CrossRef]

60. Tkaczewska, E.; Małolepszy, J. Hydration of coal-biomass fly ash cement. Constr. Build. Mater. 2009, 3, 2694-2700. [CrossRef]

61. Rutkowska, G.; Wichowski, P.; Świgoń, K.; Sobieski, P. Properties of concrete with fly ash addition from sewage sludge thermal treatment. Cem. Lime Concr. 2017, 2, 113-119. (In Polish)

62. Yusuf, R.O.; Noor, Z.Z.; Din, M.D.F.M.D.; Abba, A.H. Use of sewage sludge ash (SSA) in the production of cement and concrete-a review. Int. J. Glob. Environ. Issues 2012, 12, 214-228. [CrossRef]

63. Lin, K.L.; Lin, C.Y. Hydration characteristics of waste sludge ash utilized as raw cement material. Cem. Concr. Res. 2005, 35, 1999-2007. [CrossRef]

64. Chang, F.; Lin, J.; Tsail, C.; Wang, K. Study on cement mortar and concrete made with sewage sludge ash. Water Sci. Technol. 2010, 62, 1689-1693. [CrossRef] [PubMed]

65. Jiao, F.; Zhang, L.; Dong, Z.; Namioka, T.; Yamada, N.; Ninomiya, Y. Study on the species of heavy metals in MSW incineration fly ash and their leaching behavior. Fuel Process. Technol. 2016, 152, 108-115. [CrossRef]

(C) 2020 by the authors. Licensee MDPI, Basel, Switzerland. This article is an open access article distributed under the terms and conditions of the Creative Commons Attribution (CC BY) license (http://creativecommons.org/licenses/by/4.0/). 